\author{
CADHIUR AND ZDIC SULFIDE TUIN FIMS-SLICON \\ HYBKILE PHOTOVOLTAIC SYSTEX \\ BY \\ rasheed M. El-Awady $y^{*}$ F.A. Abouelfot ouh \\ and if.M. Abd-EInaby
}

ABSTRACT:

Tue formation of $a\left(\mathrm{zn}-\mathrm{Cd}_{-x}\right)$ 5-PS1 neterojunction solar cell under various heat treatments is investiseted in order to optimize tneir benaviour. The results obtained indickie trat subatantial improvement can be made in tre conversion and quantum efficiency of celle witn 7 about 0.75 , deposited et aubetrate tempereture of $370^{\circ} \mathrm{C}$, after anwealins in $12 / \mathrm{N}_{2}$ atmospnere at $600^{\circ} \mathrm{O}$. Under tinese conditions, minimum density of interface states good lattice matcr, snd maximu electron mobility are acnievea.

\title{
I. INTRUDUCTION :
}

Cedinium sulfiue und zince suifide films have receivea a considerable interest in photovoltele applications ir.

'wricn trese meterials and their mixture nave been acting $t s$ tre large gap window material of a neterojunction. The primary advantage of heterostructure solar cell io the enizanced snort wavelentin reaponee, reduced carrier lose frou surisece recombiration and iower tubrication coet. In order to increate the conversion efficiency of heterojunction solar cell (1), twe base niterial snoula lie in tne rane 1.1 - l.y ev, tue window material shoula neve as large sap as possioie, the Iettice wismatch ard difference in electron affinity betweer tre iwo materials snould pe minzinum. is rixed sulfiue filn $\left(\alpha n_{x}-c d_{1-x}\right) S$ could nuve en excellent lattlce ritca vitu silicon and an enerey teg ir excess of 3.0 ev by adusting tre value of $x$. An efficiency in the range $13-15$ percent is expected from eucr a sintem provided a sood quality sulfide tily can oe deposited on a properly cleaned si sirface. In tois paper we are carrying on work previously atarted (2, 3) wrici is perforned as an attenpt to relate tne prysical (eleetr-chl Esid ootical) proferties and cnemical composition of the ( $\left.u n_{x}-c a_{I-x}\right) s$ filmb to tne protovoltaic periormence of tueir aeterujuriction witu gisicon. Tre main ojjective is to study tide formetion of $\mathrm{n}\left(2 \mathrm{r}_{\mathrm{x}}-\mathrm{Cd}_{1-\mathrm{x}}\right)$ S-Psi heterojuriction under veriois aeat ireatainte in order to optinize tneir berieviour.

x Lepartment of ilectricel zrelneeriag, jnivereity of

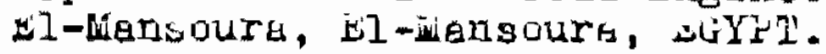

EF Enysics Departicert, hacult; of Science, univereity of rigada, Seudi árabia. 
E.64. SI-Awady, Abouelfotouh Abd-E2naby.

\section{II- Experimental:}

Neterojunction folar cello were fabricated by applying $n\left(z_{7}-C_{1-x}\right) S$ film of tinickness 3000 to $500 \%$ on a cleaned (III) aurfece of P-\$1 subatrates. The mirod sulfide films $\left(n \approx 2-5 \times 1017 \mathrm{~cm}^{-3}\right)$ were deposited by rad10 frequency sputtering from $\left(2_{n_{7}}-\mathrm{Cd}_{1-x}\right.$ ) s targets witb $x$ ranging between 0.05 and $U .85$ at different substrate temperature Tsb (be tween 150 and $\left.350^{\circ} \mathrm{C}\right)$ in argon or $\mathrm{H}_{2} \mathrm{~S}$ atmosphere at preseure of $10^{-2}$ to $10^{-4}$ torr.

Clean surface of the eubetrate is considered a a must in order to grow a sulfide film with good structure order at tne interface. Therefore a thin lager was evaporated from the surfece of tne wafer arter cnemical cleaning to remove aurface dameges oreated durine cutting and polianing of tae wafer. Then the wafers were tnermally cleaned by heating ther. at temperature over $950^{\circ} \mathrm{C}$ in $\mathrm{a}$ agh vecuum chamber in a vacuum better tian 10-7 torr to remove tine native oxidea frow tae si surface. Compleuentary surfece enalyoig includins auger electron ccaniling $A B S$, and secondary ion mass epectroscopy SIMS were employed to study tiue chemical and molecular species of the surfaces aud interfaces of tae neterojunctions. Compositional profiling wae also utilized to study tae heteroatructure tranaltion layer includias tre initial formation of the sulfide film on the 51 oubstrate. The crystaliite grain oizes in the film were me"agured uaing ocanning electron wicroacope, and information on the cryatel structure was obteined from $x$-ray dirfraction atudiea. Evaporated indium or aluminum wes used as a low-reaistance front contact to the sulfide filn. Electrical contact to tine si base was made from al evaporated at preasure of $10^{-5}$ torr and eintered at $450^{\circ} \mathrm{C}$ for $10-15$ minutes. Current - voltake, capacitance - voltage measurement were done for charecterization of the completed solar cell and for determingtion of tre deneity of interface atates respectively.

III- Resulte and Dircuerions:

The improvement in the performance of annesled $n\left(2 n_{x}-C d_{1-x}\right\}$ S-Fri solar cell due to increaging an content $x$ from 0.12 to U.75 is demonstrated in figure $I$. It lo clear that tne converaion efficlency of neterojunction prepared under the same conditione and received the same annealing trectment nas increaeed by iwo points by increasing $x$ from 0.12 to 0.7 .

The electrical caracteristics of the as grown sulfide 'limg are sumerized in Table 1 and of the onnegled films in Table 2. It is clear twat tae reaistivity increaseg witn $x$. However a drastic drop take plece after annealing in a $\mathrm{H}_{2}$ atmogpnere at temperature $550^{\circ} \mathrm{C}$, Lilnimum value of $\mathcal{\rho}=40$ obm cIn and maximur value of carrier concentretion a $=5 \times 1017 \mathrm{~cm}^{-3}$ are obtained at $x=0.12$. Tre electron mobility $\mu$ as a function of annealing condition and $x$ is shown in figure 2 . 
It is clear that $\mu$ decreaseg very olightly witin iucreasing $x$ before enrealine. After annealing $10 \mathrm{H}_{2} \mathrm{~S}$ at $600^{\circ} \mathrm{C}$ is has increased to a constant value for $x$ ranging between 0.05 and 0.3 then ctarted to decrease at nigher values of $x$. On the other nand, anuealing in $\mathrm{h}_{2}$ at the ague temperature gave riae to $a$ slight increage in $\mu^{2}$ win $x$. Larger increace was obtained due to annealing in $\mathrm{H}_{2} / \mathrm{N}_{2}$ ( $1: 1$ ) atmoephere. The present data nave ssown thet the cark reverse seturation current density so of $n\left(\mathrm{Cn}_{\mathrm{x}}-\mathrm{Cd}_{7-\mathrm{x}}\right) \mathrm{S}-\mathrm{PSi}$ neterojunction prepared at Tab $350^{\circ} \mathrm{C}$ decreases continuourly irom 2 . U mA cm-2 to $0.02 \mathrm{~m} \mathrm{~cm}-2$ by increasing $x$ from 0.05 to 0.7 due to ennesing in $\mathrm{H}_{2} / \mathrm{N}_{2}$ stmosprere at $60 \mathrm{vaC}^{\mathrm{C}}$. heterojunction anneelea in $\mathrm{H}_{2}$ or $\mathrm{H}_{2} \mathrm{~S}$ at tine same temperature nave shown a ininimum value of Jo $\theta x=0.12$ followed by an increace witn increasins $x$. The vaiues of jo

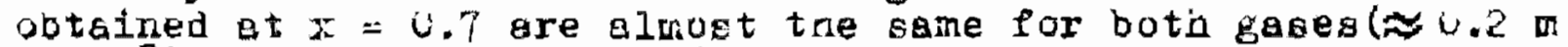
A ok-2). It ig well knowr (4) tist CdS nas a hurtate crystei structure, while es grown ins films is otrueturaliy impure(5) containine a cubic and nexagonel types of structures to $0_{0}$ iner. In tnis work, ine propor uion oI the cubic phase nGs incressed remarkably by sputterine uns in $\mathrm{H}_{2} \mathrm{~S}$ stmogpnere (pressure 10-3 torx) on clean $\mathrm{Si}$ aurfece at temperature $370^{\circ} \mathrm{C}$. After ennesline at ojo $0^{\circ} \mathrm{C}$ in $\mathrm{A}_{2} / \mathrm{N}_{2}$ atmospnere tne etruature was found to be mainly cubic (in whicn vositions of the etong in the unit celi are identical witn tiose of the diamond cubic structure of Sil. Ur the otoer hend, the crystel structure of $\left(2 n_{x}-a_{1-x}\right)$ i film prepared at $\mathrm{Tsb}=370^{\circ} \mathrm{O}$ in $\mathrm{H}_{2} \mathrm{~S}$ atmosp ie re and anneated

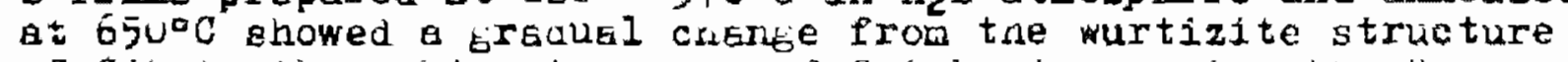
of Cas to tine cusic structure of znw by incressing the in content $x$. Proloned ennealine treatinent ( > one nour) nas in-

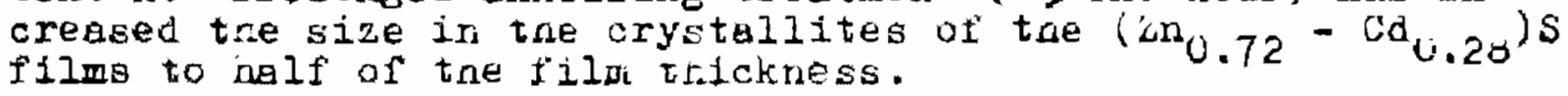

'Auker deptr profiles of $\left(\mathrm{sn}_{\mathrm{X}}-\mathrm{Cd}_{1-\mathrm{X}}\right) \mathrm{s}-\mathrm{si}$ neterojections whin $x=0.1 j$ and $x=4.8$ before and atter annealing in $\mathrm{H}_{2} / \mathrm{N}_{2}$ $(1: 1)$ at $650^{\circ} \mathrm{C}$ are shown in titures 3.0 ard 3.6 . irom fiture 3.a sulfur accomulation is soserved in reterojurctions witn lower zinc content before enmealing. Migretion of sulfur nea increased towards the interfsce of this sapple after arrealius. In fiture 3.0 junctions with $x=3.6$ did not show epprecietle chanse in alfiur concentration at tae interface due to anrealins. but $\mathrm{z}_{\mathrm{n}}$ accomiation res shom inatead. It is also observed that annealing gives rise to gharper interiace. Otherwise no major compositionel changes were obeerved.

In the case of neterojunctions with nisin zinc content $(x \approx u .75)$ niciner etrlicture order was achieved at the transitlor leyer, reduction in the wiat of tne depletion layer and stadility to nign temperature anneglinb were observed. Electron microscope studies nas snow thet the initial bondine of tne mixed sulfide riling to si surface takes place mostly throuth s etoms in junctions made irom Plias wita low sn 
E.66. El-Awbdy, hoouelfotoun \& Abd-Elnaby.

content $(x<4.25$ ). The initiel bonding take plece through Zii 5 toms in iunctione prepared fromulgn an content material $(x>0.5)$ provided tnat tne substrate temperature is nijiger inan $35 \mathrm{U}^{\circ} \mathrm{C}$. Then deasity of interface gtater was reduced due to reduction in the consentration of dangling bonds. The recomoinstion velocity was decreased from 8 I $10^{5} \mathrm{~cm}$ sec-1 for $x=0.2$ to $4 x 10^{4} \mathrm{~cm} \mathrm{sec}^{-1}$ for $x=0.8$.

IV- CONCLUSTON:

The pregent investisetion has shown that gignificsnt cnankes in the benaviour of $n\left(2 n_{x}-C_{1-x}\right)$ S-PSi golar cell can take place by varying Tsb, annesing temperature and ambience. It wes also found that un content $x$ iug a crucial inflidence on tre performence oi tne cell. Under tine aame preparation and anrealint conditions two ceses can be distinguisned.

a) In tre case of eulfide tilms with low zinc content(x about $0.12)$ the efficlency obtained is 6.3 percent, the eiectrical characteriatics ( $\rho$ and $n$ ) are optimized, tne velue of electron mobility io acceptable (150 $\left.\mathrm{cm}^{2} \mathrm{v}^{-1} \mathrm{sec}-1\right)$. However the density of interface atates due to the structurel discontinuity between Si and the sulfide filn wer so nign trat an appreciable recombination loss result in. inerefore a supreseion in loc was obeerved.

b) Increasing $2 \mathrm{n}$ content ( $x$ ebout $0.75-0.6$ ) give rise to an appreciable incrase (about 20 percent) iz botin tie converoion and cuantur efficiency compered to the former cose, is spite o: tise nigh reeistivity and jower aerrier concentration. Tris increase in etliciency ie due to reduction in tre deusity of interiece states (tnen reduction in io), reduction in electron affinity aitaterence and luprovec lattice pietco.

RERERENCES:

1. J.L. Wysocki and P. rappaport, *. Appl. Fnys. 31. (1y60) 571.

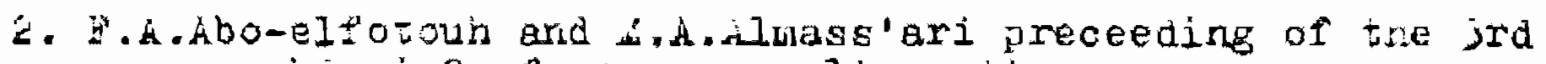
idami Conference on alternative energy sources,

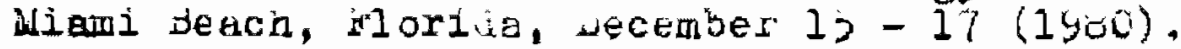

3. F.A. hou-elfotoun anà wi.h. Almase'ari, accepted t゙ar Publicetion in the journei of vacuum science and tecanoloyg (1962).

4. A. Yosnikswe ald $Y$, sakei, J. hopl. Pnyo. 45, (1974) $352 i$.

5. Y.I.Jones, C.H.li.Iitzing, D.E.Magon and V.A. Villieme, J. Pilys. 0, I, (1968) 283 . 
Mensoura Bulletin Vol. 6, o․ 2, December 1981.

Table-1. Resistivity $\rho$ and electron nobility $\mu$ and carrier concentration $n$ of the as grown sputtered $\left(2 n_{x}-C d d_{1-x}\right) S$ films as a furction o

\begin{tabular}{|c|c|c|c|c|c|c|c|c|c|}
\hline \multirow{3}{*}{$x$} & \multicolumn{3}{|c|}{ ohm $\mathrm{cm}$} & \multicolumn{3}{|c|}{$\mu \mathrm{cm}^{2} v^{-2} \sec ^{-1}$} & \multicolumn{3}{|c|}{$\mathrm{n} \times 10^{-16} \mathrm{~cm}^{-3}$} \\
\hline & \multicolumn{3}{|c|}{$\operatorname{Tsb}{ }^{\circ} \mathrm{C}$} & \multicolumn{3}{|c|}{$T s \mathrm{~b}{ }^{\circ} \mathrm{C}$} & \multicolumn{3}{|c|}{$\operatorname{Tsb}{ }^{\circ} \mathrm{C}$} \\
\hline & 150 & 250 & 350 & 150 & 250 & 350 & 150 & 250 & 350 \\
\hline 0.0 & 200 & 300 & 450 & 110 & 120 & 125 & 8 & 12 & 15 \\
\hline 0.15 & 500 & 450 & 350 & 120 & 110 & 125 & 15 & 25 & 35 \\
\hline 0.25 & 600 & 550 & 500 & 110 & 215 & 120 & 15 & 20 & 35 \\
\hline 0.5 & 800 & 780 & 750 & 100 & 205 & 110 & 12 & 28 & 30 \\
\hline 0.72 & 2000 & 1000 & 950 & 80 & 80 & 75 & 10 & 18 & 20 \\
\hline 0.85 & 1100 & 1050 & 1050 & 50 & 55 & 50 & 8 & 12 & 15 \\
\hline
\end{tabular}

Table 2 . $P$ and of $\left(2 \pi_{x}-C C_{2-x}\right) S$ films prepared at $T s b=350^{\circ} \mathrm{C}$ after annealing at temperature $\mathrm{Ta}=600^{\circ} \mathrm{C}$ in $\mathrm{H}_{2}(\mathrm{a})$, $\left(\mathrm{H}_{2} / \mathrm{N}_{2}\right)(\mathrm{b})$, and $\mathrm{H}_{2} \mathrm{~S}(\mathrm{c})$.

\begin{tabular}{|c|c|c|c|c|c|c|c|}
\hline \multicolumn{2}{|c|}{$x$} & 0.0 & 0.15 & 0.25 & 0.5 & 0.72 & 0.85 \\
\hline \multirow{3}{*}{$\rho$} & a & 60 & 40 & 190 & 280 & 300 & 320 \\
\hline & b & 70 & 115 & 250 & 350 & 400 & 400 \\
\hline & $c$ & 85 & 120 & 260 & 400 & 450 & 450 \\
\hline \multirow{3}{*}{$\mathrm{n}$} & a & $2 \theta$ & 60 & 55 & 40 & 30 & 30 \\
\hline & b & 18 & 4.5 & 40 & 30 & 20 & 20 \\
\hline & c & 15 & 40 & 35 & 30 & 20 & 20 \\
\hline
\end{tabular}


L',68. kl-hwady, Abouelfotoun \& ibd-Eilnaby.

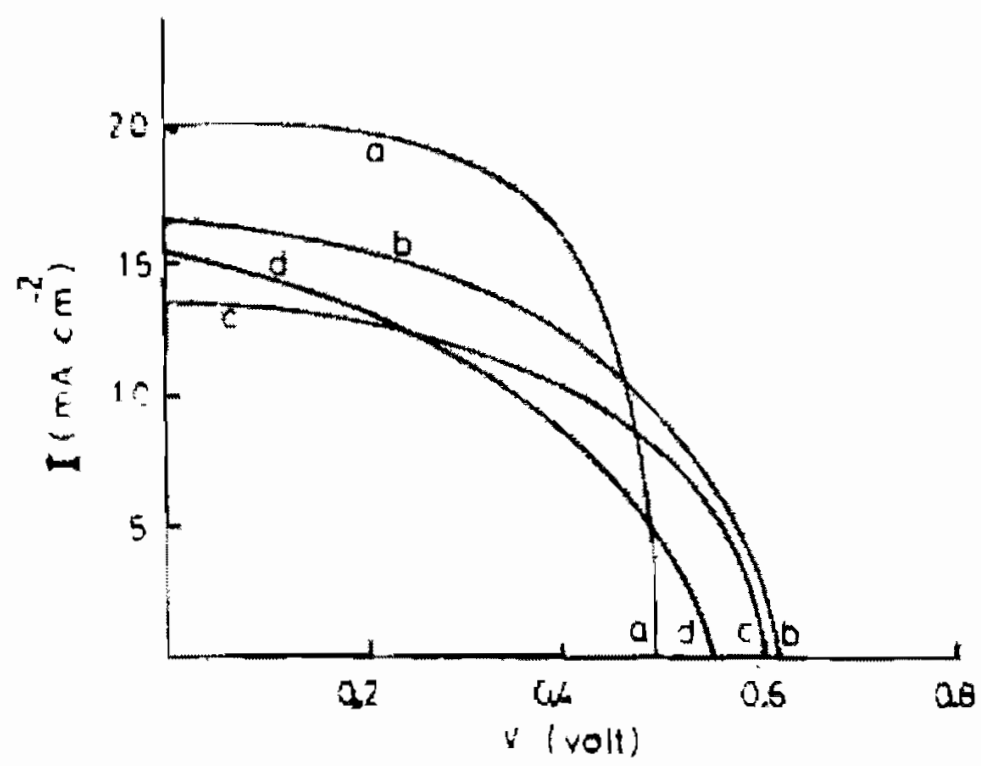

Fig.(1): I-V characteristics of (a) Si homojunction solar cell (10 percent eficiency), (b) $n\left(\mathrm{cn}_{\mathrm{x}}-\mathrm{Cd} 1-\mathrm{x}\right.$ )S-pSi heterojunctions wit $x+v .75$ and (c) for $x+4.12$, and nCas - psi.

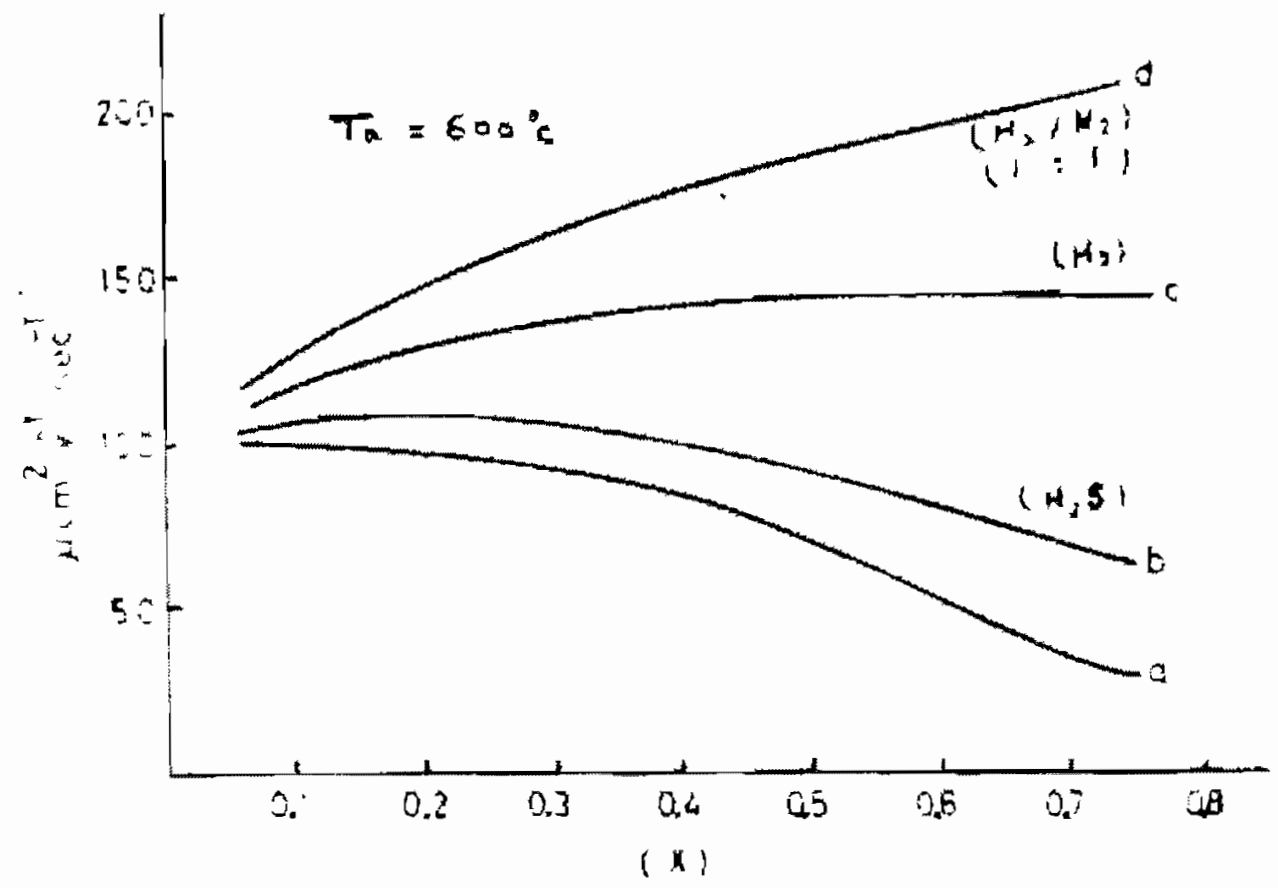

Fig. (2): Electron mobility $\mu$ of $n\left(2 n_{x}-C d d_{1-x}\right) S$ filmo sputtered at $T_{g b}=350^{\circ} \mathrm{C}$ as a function of $\pi$, before annealing (a) and after ennealing (b, $G$, and $d$ ). 


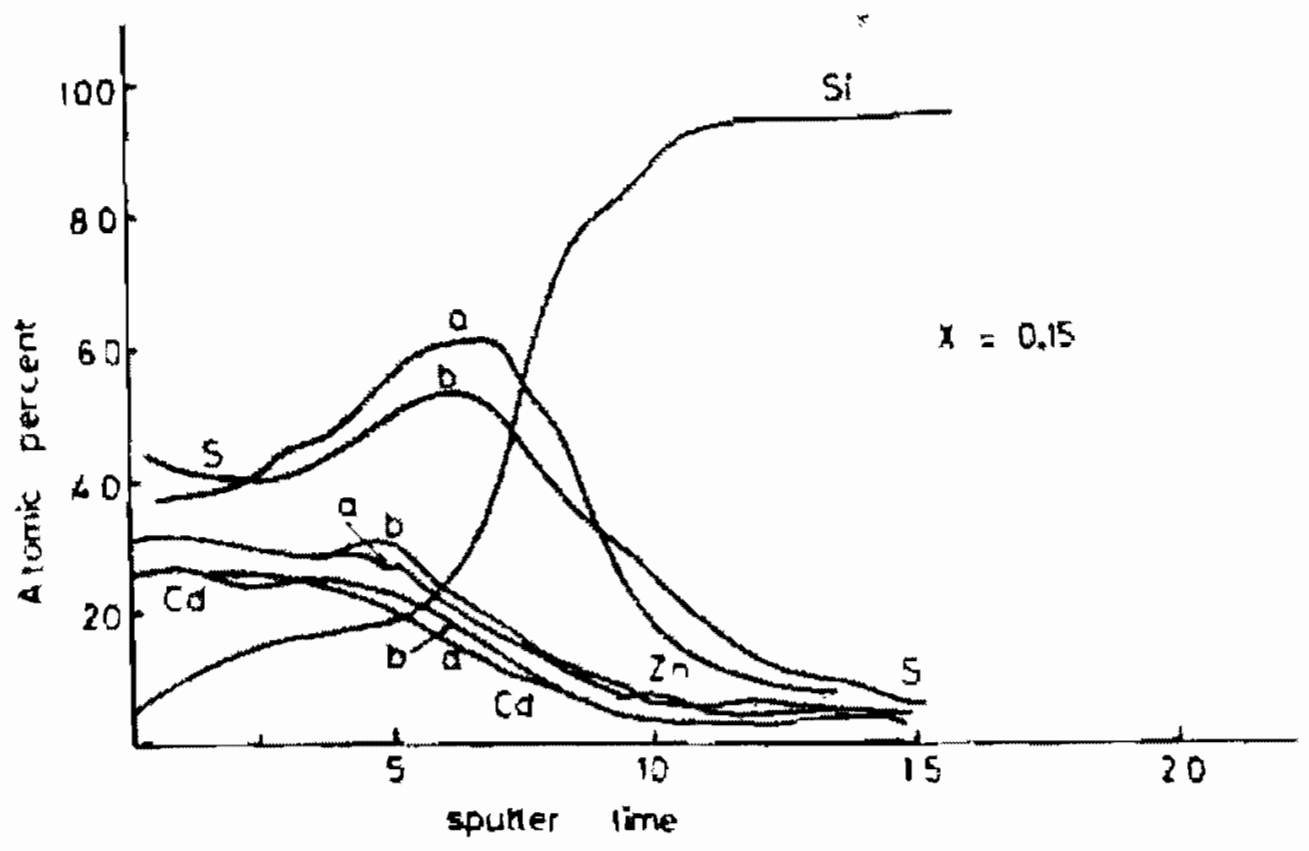

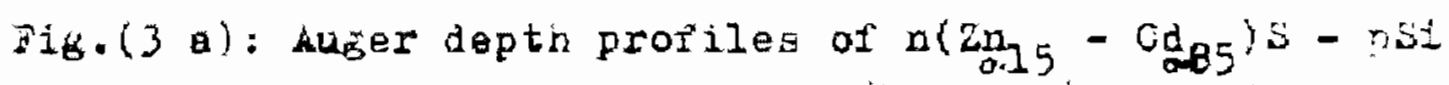
peterojunction berore (IInes b) anü arter aniesline (Iines $a$ ).

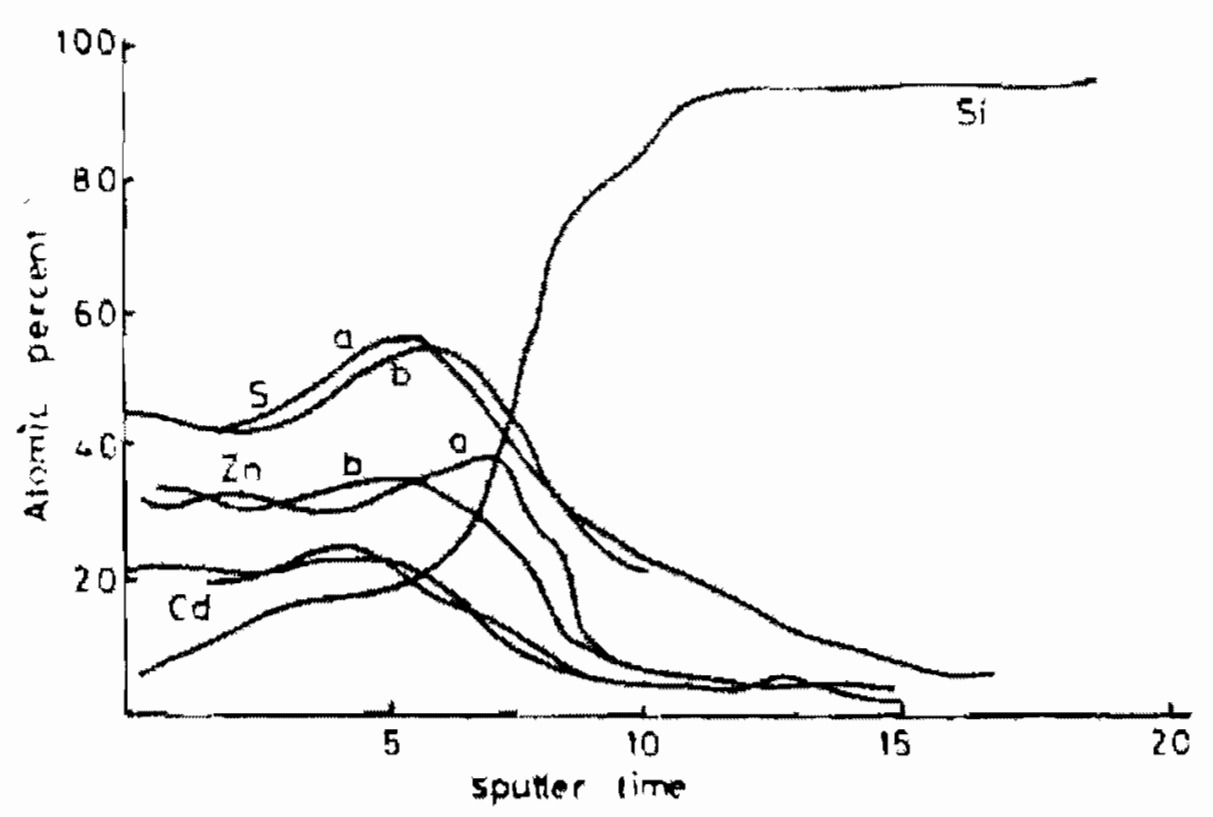

HAd. (3 b): wuter depth protices of a $\left(2 n_{0.8}-0 d_{0.2}\right) s-p i$ betore (Ilnes o) and gtoer unneaing (izines $e$ ). 